\title{
Biochelator Assisted Phytoremediation for Cadmium (Cd) Pollution in Paddy Field
}

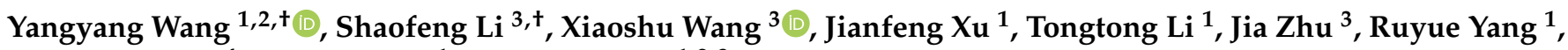 \\ Jinsheng Wang ${ }^{4}$, Ming Chang ${ }^{1, *}$ and Lei Wang ${ }^{1,2,3, *}$
}

1 State Key Laboratory of Environmental Criteria and Risk Assessment, Chinese Research Academy of Environmental Science, Beijing 100012, China; wangyangyang0317@163.com (Y.W.); Xujifengat@163.com (J.X.); 18811785922@163.com (T.L.); yangruyue@ucas.ac.cn (R.Y.)

2 The Guangxi Key Laboratory of Theory and Technology for Environmental Pollution Control, Guilin University of Technology, Guilin 541004, China

3 Department of Building Environmental Engineering, Shenzhen Polytechnic Institute, Shenzhen 518055, China; lshaofeng@szpt.edu.cn (S.L.); xshuwang@163.com (X.W.); zhujia@szpt.edu.cn (J.Z.)

4 Shenzhen BeiYu Environmental Technology Co., Ltd., Shenzhen 518063, China; wjs025@163.com

* Correspondence: changming@craes.org.cn (M.C.); wangleicraes@163.com (L.W.)

+ These authors contributed equally to this work.

Citation: Wang, Y.; Li, S.; Wang, X.; Xu, J.; Li, T.; Zhu, J.; Yang, R.; Wang, J.; Chang, M.; Wang, L. Biochelator Assisted Phytoremediation for Cadmium (Cd) Pollution in Paddy Field. Sustainability 2021, 13, 12170. https://doi.org/10.3390/ su132112170

Academic Editor: Elena Rada

Received: 21 August 2021

Accepted: 19 October 2021

Published: 4 November 2021

Publisher's Note: MDPI stays neutral with regard to jurisdictional claims in published maps and institutional affiliations.

Copyright: (c) 2021 by the authors. Licensee MDPI, Basel, Switzerland. This article is an open access article distributed under the terms and conditions of the Creative Commons Attribution (CC BY) license (https:/ / creativecommons.org/licenses/by/ $4.0 /)$.

\begin{abstract}
To evaluate the efficacy of biochelators for phytoremediation of cadmium (Cd), effects of biochelators (humic acid, HA; polyaspartic acid, PASP; rhamnolipid, RLs) and synthetic chelator (sodium tripolyphosphate, STPP) on the growth, accumulation, and antioxidant index of Cd were investigated in Iris sibirica L. The results indicated that the addition of HA increased the dry weight of leaves and stems, and the addition of PASP, RLs, and STPP increased the growth of leaves but inhibited the growth of stems. The determination of $\mathrm{Cd}$ accumulation indicated that HA decreased the content of $\mathrm{Cd}$ in all tissues, while the addition of PASP, RLs, and STPP increased the accumulation of $\mathrm{Cd}$ in stems and roots. In addition, the determination of superoxide dismutase (SOD), peroxidase (POD), and catalase (CAT) activities indicated that the treatment of PASP and RLs increased the activities of antioxidant enzymes, which might be beneficial to the resistance of Cd for Iris sibirica L. Overall, these results indicated that biochelators may improve the phytoremediation efficacy of Iris sibirica L. on Cd polluted paddy field. Among the tested chelators, PASP exhibited the best comprehensive efficacy and the highest commercial potential.
\end{abstract}

Keywords: cadmium; paddy field; phytoremediation; biochelator; Iris sibirica L.

\section{Introduction}

Cadmium (Cd) is a highly toxic pollutant and is widely distributed in environments [1]. Due to its strong mobility, $\mathrm{Cd}$ can easily enter water, soil, and paddy field, and then accumulate in plants including crops. Afterwards, $\mathrm{Cd}$ may be transferred to animals through the food chain, and it will also threaten the health of humans [2,3]. Therefore, scientists are actively seeking more economical methods to repair Cd-polluted areas. At present, adsorption and phytoremediation are commonly used methods to repair Cd-polluted in the environment. The method of adsorption is mainly to remove $\mathrm{Cd}^{2+}$ in the environment through the preparation of new adsorption functional materials (such as biochar [4], cellulose [5], etc.). Although the adsorbents are useful for the pollution of $\mathrm{Cd}$, they are difficult to remove from the environment, which may cause new environmental problems.

Phytoremediation is a promising and widely used treatment method for Cd-polluted paddy fields [6]. Up to date, a large number of hyperaccumulators have been identified, such as Brassicaceae and Thlaspi. The plant of Iris sibirica L. can grow well on both wetlands and drylands. As reported, Iris sibirica L. has a high hyperaccumulation ability of $\mathrm{Cd}$ and therefore exhibits a high repair potential for $\mathrm{Cd}$-polluted paddy fields [7]. Bioavailable $\mathrm{Cd}$ 
only occupy a small proportion of the total $\mathrm{Cd}$ in polluted soils. To further enhance the phytoremediation efficacy and shorten the remediation duration, the addition of chelators can increase the mobility of $\mathrm{Cd}$, thereby promoting the accumulation of $\mathrm{Cd}$ in plants. Generally speaking, according to the source of chelators, it can be divided into two types, including synthetic chelators and biochelators. Compared with the synthetic chelators, biochelators exhibit better surface activity and higher biodegradability, thereby improving the remediation efficacy and reducing the risk of secondary pollution [8].

According to previous reports, the application of fertilizers not only improves soil fertility but also improves the phytoremediation efficacy of plants on heavy metals [9]. The possible reasons include the presence of biochelators in the fertilizers, which enhance the accumulation of heavy metals in plants. For example, humic acid (HA) is a green polymer and fertilizer, and its chemical structure contains several functional groups with significant chelating ability [10]. Another fertilizer, polyaspartic acid (PASP), is also a good chelator. These biochelators may also be used as candidates to improve the ability of phytoremediation. In addition, the biosurfactant rhamnolipid (RLs) produced by Pseudomonas bacteria exhibits high specificity, biodegradability, and biocompatibility and a strong affinity to metals including $\mathrm{Cd}$ through its single carboxyl group [11,12]. However, so far, no direct experimental evidence has been reported to validate this hypothesis. In addition, these fertilizers are generally cheap. If they could effectively improve the effect of phytoremediation, a high commercial value would be exhibited.

In this study, to detect the effect of biochelators (HA, PASP, RLs) on the phytoremediation of Cd using Iris sibirica L., seedlings were cultured in Cd-polluted medium with HA, PASP, and RLs. In addition, the typical synthetic chelator sodium tripolyphosphate (STPP) was closed in the phytoremediation efficacy test, and solution without these four chelators was used as a negative control. Afterwards, the changes of biomass, $\mathrm{Cd}$ accumulation, and antioxidant parameters were compared among treatments. These results provide basic information for understanding the mechanisms of fertilizers to improve the phytoremediation efficacy and also contribute to the further application of biochelators on the phytoremediation of Cd-polluted areas.

\section{Materials and Methods}

\subsection{Plant Culture and Treatments with $\mathrm{Cd}$ and Chelators}

Iris sibirica L. seedlings with six months old and equal weight were purchased from a nursery garden for hydroponic culture in the Daxing district, Beijing, China and then cultured in $12 \mathrm{~L}$ plastic containers. Each container contained five plants with $10 \mathrm{~L}$ of nutrient solution. After acclimation for two weeks, seedlings were carefully rinsed with deionized water and then exposed to the nutrient solution $\left(5.00 \mathrm{mmol} \mathrm{KNO}{ }_{3}, 5.00 \mathrm{mmol} \mathrm{Ca}\left(\mathrm{NO}_{3}\right)_{2} \cdot 4 \mathrm{H}_{2} \mathrm{O}, 1.00 \mathrm{mmol} \mathrm{KH}_{2} \mathrm{PO}_{4}\right.$, $2.00 \mathrm{mmol} \mathrm{MgSO}_{4} \cdot 7 \mathrm{H}_{2} \mathrm{O}, 9.00 \mathrm{mmol} \mathrm{MnCl}_{2} \cdot 4 \mathrm{H}_{2} \mathrm{O}, 0.80 \mathrm{mmol} \mathrm{ZnSO} \cdot 7 \mathrm{H}_{2} \mathrm{O}, 0.30 \mathrm{mmol}$ $\mathrm{CuSO}_{4} \cdot 5 \mathrm{H}_{2} \mathrm{O}, 4.00 \mathrm{mmol} \mathrm{H}_{3} \mathrm{BO}_{3}, 0.01 \mathrm{mmol} \mathrm{H}_{2} \mathrm{MoO}_{4} \cdot \mathrm{H}_{2} \mathrm{O}$ and $\left.0.80 \mathrm{mmol} \mathrm{Fe}\left(\mathrm{SO}_{4}\right)_{3}\right)$ [13] containing $25.00 \mathrm{mg} \mathrm{L}^{-1} \mathrm{Cd}^{2+}$ (using $\mathrm{Cd}\left(\mathrm{NO}_{3}\right)_{2} \cdot 4 \mathrm{H}_{2} \mathrm{O}$ ). Meanwhile, HA, PASP, RLs, and STPP treatments were set at five concentrations, including $0.00,1.00,3.00,5.00,7.00 \mathrm{mg} \mathrm{L}^{-1}$. The $\mathrm{pH}$ of the solution was adjusted to between 5.8 and 6.0 in all reactions. Each treatment was repeated three times.

The plants were then cultured for 60 days under the following conditions: temperature from 21.0 to $28.0^{\circ} \mathrm{C}$, photoperiod of $15-\mathrm{h}$, and light intensity of 9 -h. During this period, water levels were maintained by adding deionized water daily and the culture solution was completely replaced every 7 days.

After 60 days of culture, plants were rinsed with $0.01 \mathrm{M} \mathrm{HCl}$ solution and then deionized water to remove the adsorption of $\mathrm{Ca}^{2+}$ on surfaces. Next, each seedling was separated into leave, stem, and root in the laboratory. Each tissue was separated into two parts. One part was frozen immediately in liquid nitrogen and then maintained at $-80.00{ }^{\circ} \mathrm{C}$ for enzymatic analysis. Another part was dried at $70.00{ }^{\circ} \mathrm{C}$ for $72 \mathrm{~h}$ and then used for determination of dry weight and Cd content. 


\subsection{Analysis of $\mathrm{Cd}$ Content}

Dry tissue samples were ground into powders and then sieved through a $160.00 \mu \mathrm{m}$ pore-sized sieve. Approximately $0.2 \mathrm{~g}$ of powder was precisely weighed and then digested in concentrated $\mathrm{HNO}_{3}$ solution until the solution became colorless [14]. After removing $\mathrm{HNO}_{3}$ by heating, the residues were then dissolved in $7 \% \mathrm{HNO}_{3}$ solution. Cd contents were determined using an Inductively Coupled Plasma Mass-Spectrophotometer (ICP-MS) (Agilent 7500cx).

Based on the data of stems and leaves, $\mathrm{Cd}$ concentration $\left(\mathrm{C}_{\text {shoot }}\right)$ and accumulation in shoot is calculated using the following equation.

$$
\mathrm{C}_{\text {shoot }}=\left(\mathrm{C}_{\text {stem }} \times \mathrm{M}_{\text {stem }}+\mathrm{C}_{\text {leaf }} \times \mathrm{M}_{\text {leaf }}\right) /\left(\mathrm{M}_{\text {stem }}+\mathrm{M}_{\text {leaf }}\right)
$$

$\mathrm{Cd}$ accumulation in shoot $=\left(\mathrm{C}_{\text {stem }} \times \mathrm{M}_{\text {stem }}+\mathrm{C}_{\text {leaf }} \times \mathrm{M}_{\text {leaf }}\right)$

where $C$ is the concentration of $C d$ and $M$ is the biomass of tissue.

Bioaccumulation factors (BCF) and translocation factors (TCF) were calculated as follows.

$\mathrm{BCF}=\mathrm{Cd}$ concentration in shoot $/ \mathrm{Cd}$ concentration in solution.

$\mathrm{TCF}=\mathrm{Cd}$ concentration in shoot $/ \mathrm{Cd}$ concentration in root.

\subsection{Measurement of Antioxidant Indices}

Superoxide dismutase (SOD, EC 1.15.1.1), peroxidase (POD, EC 1.11.1.7), and catalase (CAT, EC 1.11.1.6) activities in both leaves and roots were assayed using commercial kits developed by the Solarbio Lifer Sciences Company (Beijing, China) following the manufacture's protocols.

\subsection{Statistical Analyses}

One-way analysis of variance, correlation, and regression analysis were performed with SPSS 19.0 statistical software. The data listed in the article are the average of 3 repetitions. Among them, one-way analysis of variance mainly uses ANOVA test, assuming that a numeric variable means in groups drawn from populations with the same mean values grouped by elements of a nominal variable. In addition, correlation and regression analysis mainly use Pearson test and a line relationship test, respectively, assuming that the biochelators concentration in solution and the mass of dry plant (or $\mathrm{Cd}$ concentration in the plant) exhibited a positive correlation.

\section{Results}

\subsection{Effects of Chelators on Iris Sibirica L. Growth in Cd Polluted Media}

In the control group ( $\mathrm{Cd}$ without chelators), the plants exhibited slight detrimental symptoms, such as yellowish color and thinner seedlings (Figure 1). Comparatively, the plants showed vigorous growth under all chelators treatments, which were greener in color and thicker in diameter. Four selected chelators showed to be effective to tolerate Iris sibirica $\mathrm{L}$. under the same $\mathrm{Cd}$ stress. In alkaline and acidic soils, the bioavailability of $\mathrm{Cd}$ is $5.02 \%$ and $48.50 \%$, respectively. Whereas Cd added in the weakly acidic solution is in the form of $\mathrm{Cd}^{2+}$, which is bioavailable for the Iris sibirica $\mathrm{L}$. in this study. Cd is a toxic heavy metal. The chelator detoxify and sequester metal ions by binding them and metal-bridging mechanisms, which enables plants to tolerate and evolve resistance to metal contamination. As reported, chelator with hydrophilic and hydrophobic portions was able to decrease toxicity by the complexation of forming micelles with metals, which helps plants develop resistance to heavy metal contamination [15]. 


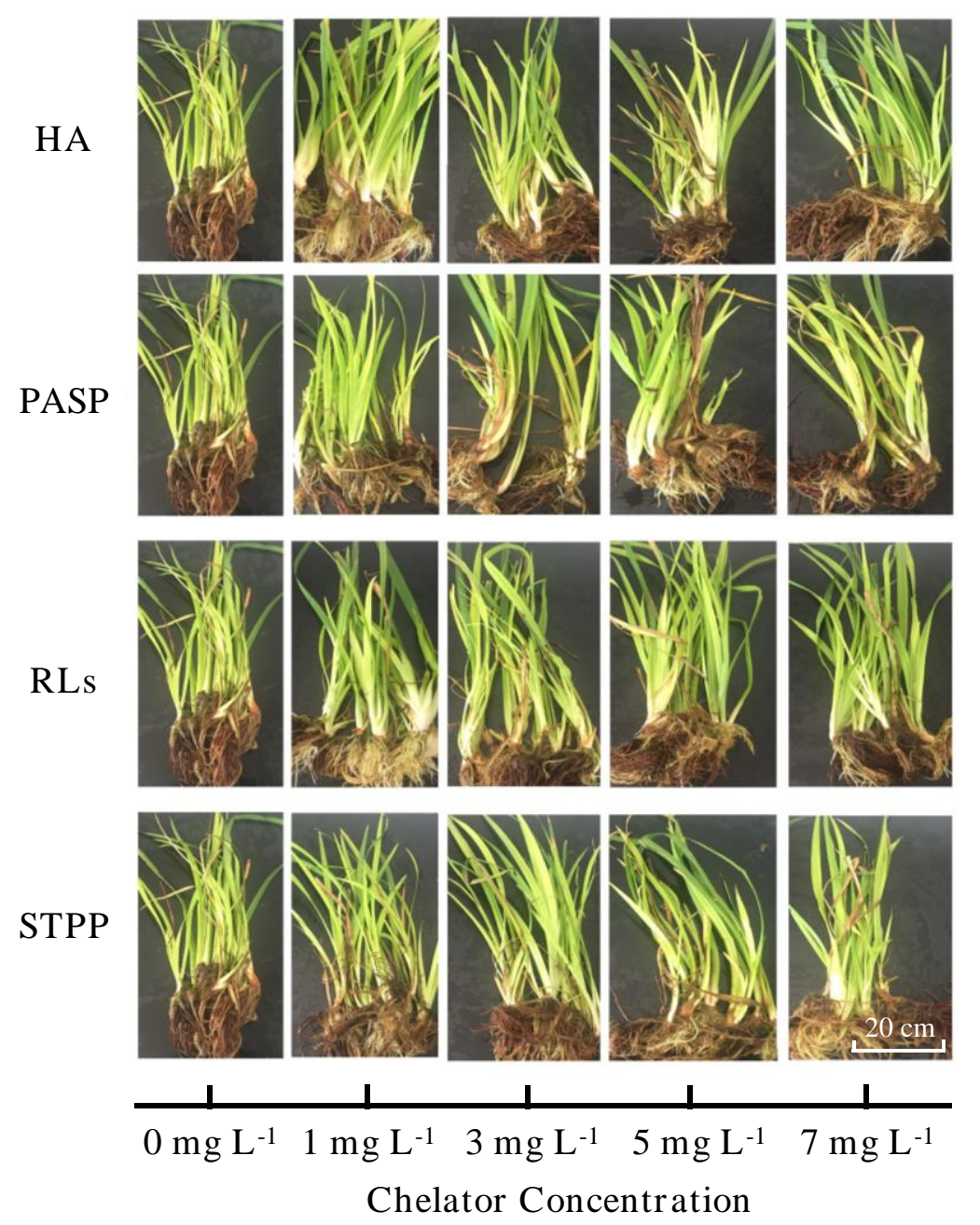

Figure 1. Pictures of Iris sibirica L. in Cd polluted media after addition of different concentrations of HA, PASP, RLs, and STPP.

Compared with a single $\mathrm{Cd}$ treatment, the addition of HA significantly increased the dry weights of leaves, stems, and roots. Especially, the leaf dry weight of $3 \mathrm{mg} \mathrm{L}^{-1}$ HA treatment, stem, and root dry weights in treatment with $7 \mathrm{mg} \mathrm{L}^{-1} \mathrm{HA}$ were greatly higher than in the control group (Figure 2), indicating that different concentrations of HA could stimulate the growth of different organ of the Iris sibirica L. Totally, experimental data manifest that the total dry weight of root was all more than the sum of leaf and stem in Iris sibirica L. Especially, treatments with all concentrations of PASP, RLs, and STPP significantly decreased the dry weight of leaf but increased the dry weight of root in comparison to a single Cd treatment. Although significant effects were also observed on the dry weight of stem in treatments with four chelators, the changing amplitudes were rather small (Figure 2). These results indicate that PASP, RLs, and STPP may be beneficial to the growth of roots but damage the leaves, which is consistent with previous studies $[16,17]$.

Among the four chelators, the addition of HA revealed better promoting effect on the dry weight of stem and leaf, but the promoting effect on the dry weight of root is less than that of the other three chelators (Figure 2). This indicates that the chelators at suitable concentrations could promote the growth of Iris sibirica L. by facilitating the absorption of fertilizers [18]. The best concentration of HA on plant leaves and stems is $3 \mathrm{mg} \mathrm{L}^{-1}$ and $7 \mathrm{mg} \mathrm{L}^{-1}$. Both HA or PASP are considered as good fertilizers; therefore, their addition could promote the growth of leaves of Iris sibirica L. In comparison with HA and PASP, the application of RLs and STPP could only stimulates the roots and stems growth and inhibited the leaves growth of Iris sibirica L., which is unfavorable for the Cd removal by 
phytoremediation. This is in agreement with a previous report that in some kinds and dosages chelator can decrease plant biomass [19]. From the results, it can be deduced that all the chelators, especially HA and PASP, have a very strong ability to endue Iris sibirica L. with tolerance to resist $\mathrm{Cd}$ contamination, which makes hyperaccumulation possible.

The four chelators revealed different effects on plant growth, indicating that their interaction mechanisms with $\mathrm{Cd}$ may be different. To investigate the reasons, $\mathrm{Cd}$ accumulation and antioxidant indices were determined.

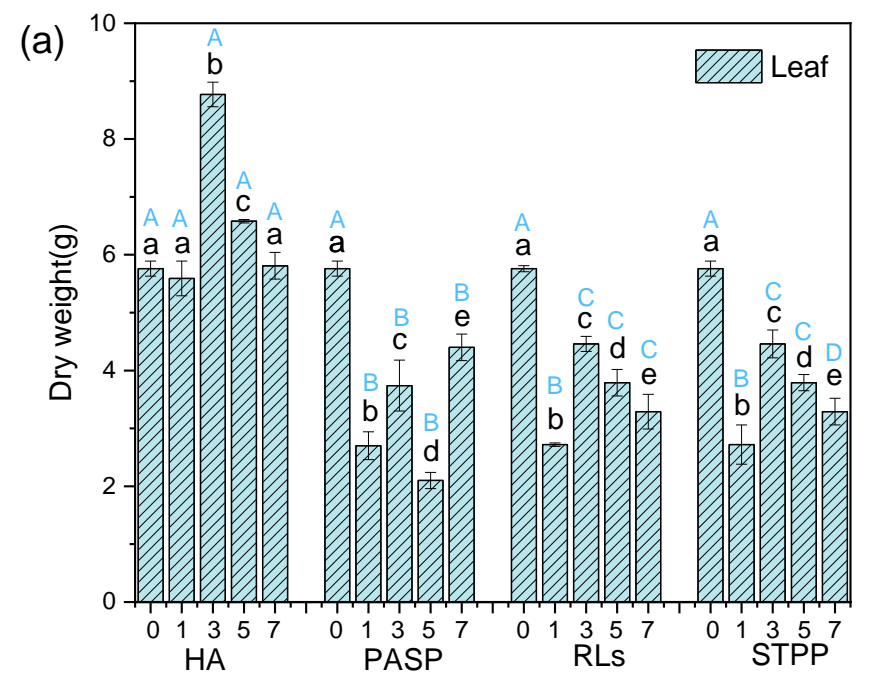

Treatment $\left(\mathrm{mg} \mathrm{L}^{-1}\right)$

(b)

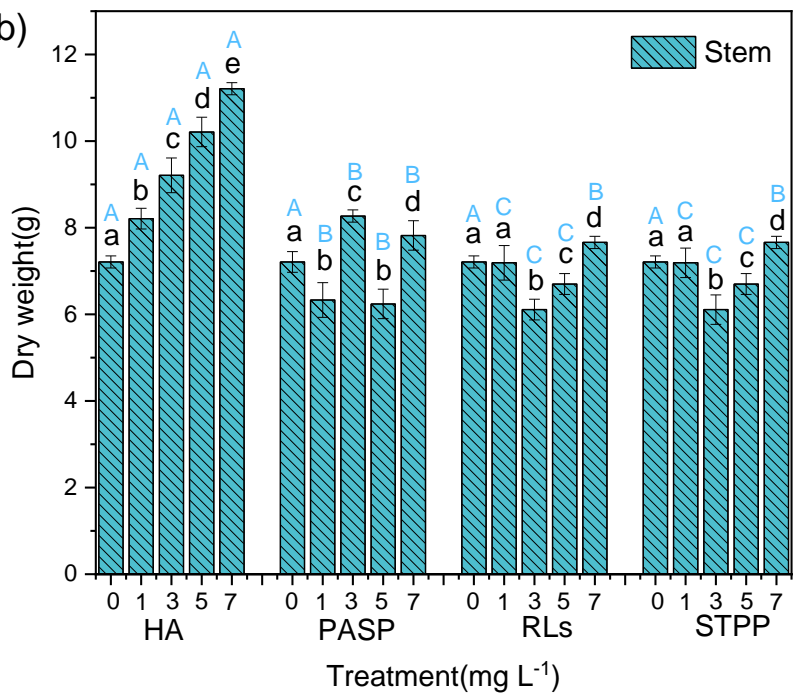

(c)

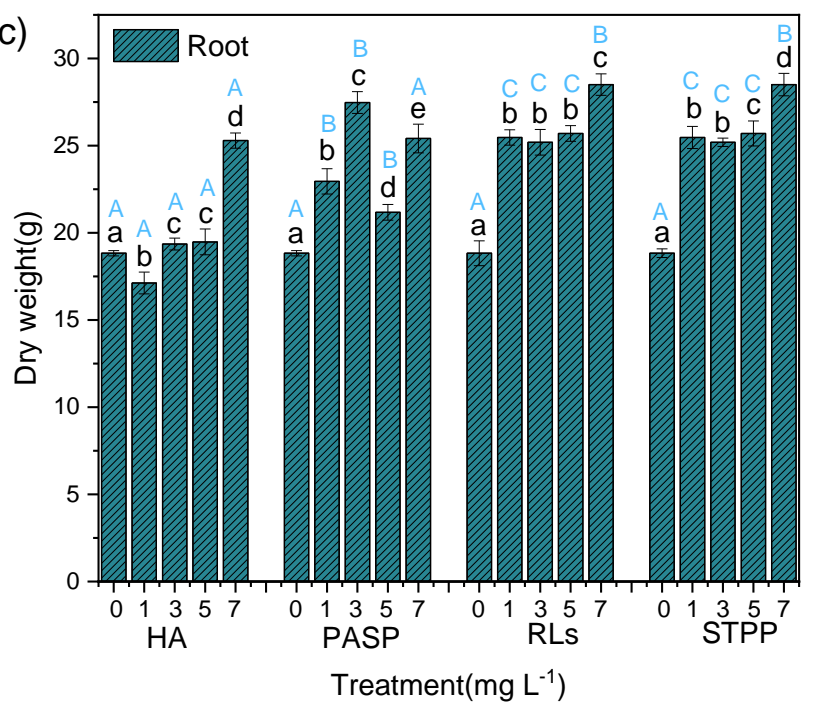

Figure 2. Dry weights of leaves (a), stems (b), and roots (c) of Iris sibirica L. in response to treatments with HA, PASP, RLs, and STPP under the stress of $25.00 \mathrm{mg} \mathrm{L}^{-1} \mathrm{Cd}$. Data are means \pm S.D. $(n=3)$. Different uppercase letters $(\mathrm{A}-\mathrm{D})$ indicate significant differences between treatments with different chelators at the same concentration, and different lowercase letters (a-e) indicate significant differences between different concentrations of the same chelator.

\subsection{Effects of Chelators on Cd Accumulation in Iris Sibirica L. Tissues}

In order to assess the ability to resist Cd erosion of Iris sibirica $\mathrm{L}$. influenced with chelators, a series of assays are conducted by culturing the plants within 60 days. Compared with single $\mathrm{Cd}$ exposure, the addition of $\mathrm{HA}$ decreased the accumulation of $\mathrm{Cd}$ in leaves, stems, and roots. Under $1.0 \mathrm{mg} \mathrm{L}^{-1}$ PASP, and RLs treatment, the accumulation of $\mathrm{Cd}$ in leaves, stems, and roots was significantly higher than that in the control. However, with the further increase of the chelator concentration, the accumulation of $\mathrm{Cd}$ exhibited a decreasing tendency. Additionally, STPP treatments all significantly increased 
the accumulation of $\mathrm{Cd}$ in leaves, stems, and roots compared with the control (Table 1 and Figure 3). These results were highly consistent with the changes in dry weight. Accumulating more $\mathrm{Cd}$ would decrease the biomass of the corresponding tissue and conversely, lower accumulation of $\mathrm{Cd}$ may promote growth. It was found that the accumulation of $\mathrm{Cd}$ in this study can reach up to $2703.24 \mathrm{mg} \mathrm{kg}^{-1}$, which is far beyond the phytoremediation method (Sedum plumbizincicola, $541.36 \mathrm{mg} \mathrm{kg}^{-1}$ ) [20] and the plant-microbe combined remediation method (Cynodon dactylon (L.) Pers-ZZ-2, $872.01 \mathrm{mg} \mathrm{kg}^{-1}$ ) [21]. This shows that this technology has obvious advantages in the phytoremediation field. In addition, PASP at $1.00 \mathrm{mg} \mathrm{L}^{-1}$ proved to be the best one among the four chelators with different concentration; the highest value of 36.66 and $81.75 \mathrm{mg}$ was acquired at $1.00 \mathrm{mg} \mathrm{L}^{-1} \mathrm{PASP}$, which provided further evidence that PASP was the most effective one among the four chelators and $1.00 \mathrm{mg} \mathrm{L}^{-1}$ dosage may still be proper. According to the above results, the enhancement of four chelators about Cd uptake capabilities followed the decreasing order: PASP $>$ STPP > RLs > > HA.

Table 1. Effects of chelators on Cd accumulation in roots, stems, and leaves of Iris sibirica L.

\begin{tabular}{|c|c|c|c|c|}
\hline \multicolumn{2}{|c|}{ Treatment $\left(\mathrm{mg} \mathrm{L}^{-1}\right)$} & \multirow{2}{*}{$\begin{array}{l}\left.\text { Leaf (mg kg } \mathbf{~ k}^{-1}\right) \\
723.53 \pm 1.96 \mathrm{a}\end{array}$} & \multirow{2}{*}{$\begin{array}{l}\text { Stem }\left(\mathbf{m g ~ k g} \mathbf{~ k g}^{-1}\right) \\
1419.27 \pm 3.77 \mathrm{a}\end{array}$} & \multirow{2}{*}{$\begin{array}{l}\left.\text { Root (mg kg }{ }^{-1}\right) \\
1576.36 \pm 2.50 \mathrm{a}\end{array}$} \\
\hline \multirow{5}{*}{ HA } & ck & & & \\
\hline & 1.00 & $623.34 \pm 3.21 \mathrm{~b}$ & $1396.93 \pm 3.51 \mathrm{~b}$ & $1464.41 \pm 1.99 \mathrm{~b}$ \\
\hline & 3.00 & $374.55 \pm 2.16 c$ & $796.81 \pm 4.26 c$ & $1233.12 \pm 2.43 c$ \\
\hline & 5.00 & $404.26 \pm 3.22 \mathrm{~d}$ & $802.20 \pm 0.87 c$ & $963.11 \pm 5.41 \mathrm{~d}$ \\
\hline & 7.00 & $297.11 \pm 4.17 \mathrm{e}$ & $458.39 \pm 3.79 \mathrm{~d}$ & $970.02 \pm 2.57 \mathrm{e}$ \\
\hline \multirow{5}{*}{ PASP } & ck & $723.53 \pm 1.96 \mathrm{a}$ & $1419.27 \pm 3.77 \mathrm{a}$ & $1576.36 \pm 2.50 \mathrm{a}$ \\
\hline & 1.00 & $1315.12 \pm 3.30 \mathrm{~b}$ & $2594.37 \pm 0.63 b$ & $2703.24 \pm 5.7 b$ \\
\hline & 3.00 & $666.04 \pm 4.37 \mathrm{c}$ & $1505.88 \pm 7.83 c$ & $2531.59 \pm 9.67 c$ \\
\hline & 5.00 & $724.98 \pm 5.14 \mathrm{~d}$ & $1796.38 \pm 2.62 \mathrm{~d}$ & $2528.22 \pm 11.58 d$ \\
\hline & 7.00 & $1076.51 \pm 2.17 \mathrm{e}$ & $1865.28 \pm 2.72 \mathrm{e}$ & $2583.39 \pm 4.61 \mathrm{e}$ \\
\hline \multirow{5}{*}{ RLs } & ck & $723.53 \pm 1.96 \mathrm{a}$ & $1419.27 \pm 3.77 \mathrm{a}$ & $1576.36 \pm 2.50 \mathrm{a}$ \\
\hline & 1.00 & $1053.64 \pm 6.03 b$ & $2525.59 \pm 3.43 b$ & $2223.57 \pm 5.52 b$ \\
\hline & 3.00 & $612.46 \pm 1.41 c$ & $1603.71 \pm 2.91 \mathrm{c}$ & $1819.81 \pm 13.09 \mathrm{c}$ \\
\hline & 5.00 & $656.5 \pm 8.47 \mathrm{~d}$ & $1554.65 \pm 3.34 \mathrm{~d}$ & $2117.12 \pm 11.87 \mathrm{~d}$ \\
\hline & 7.00 & $847.67 \pm 2.31 \mathrm{e}$ & $1851.06 \pm 5.31 \mathrm{e}$ & $1886.53 \pm 4.31 \mathrm{e}$ \\
\hline \multirow{5}{*}{ STPP } & ck & $723.53 \pm 1.96 \mathrm{a}$ & $1419.27 \pm 3.77 \mathrm{a}$ & $1576.36 \pm 2.50 \mathrm{a}$ \\
\hline & 1.00 & $762.24 \pm 0.44 b$ & $1552.32 \pm 18.16 \mathrm{~b}$ & $1665.72 \pm 10.15 b$ \\
\hline & 3.00 & $890.18 \pm 0.94 \mathrm{c}$ & $1860.87 \pm 7.43 c$ & $2392.46 \pm 6.58 c$ \\
\hline & 5.00 & $878.05 \pm 4.60 \mathrm{~d}$ & $1908.95 \pm 1.13 \mathrm{~d}$ & $2433.66 \pm 12.29 \mathrm{~d}$ \\
\hline & 7.00 & $847.93 \pm 3.65 \mathrm{e}$ & $2020.71 \pm 4.53 \mathrm{e}$ & $2503.04 \pm 8.64 \mathrm{e}$ \\
\hline
\end{tabular}

Data are means \pm S.D. $(n=3)$. ck: control check. Different letters indicate significant differences between different concentrations of the same chelator.

The four different chelators exerted different actions on the accumulation of $\mathrm{Cd}$ in organs of Iris sibirica L., which might be associated with their chemical structures. First, HA is a relatively large molecule and may not be directly absorbed by plant roots. Thus, the chelation of $\mathrm{Cd}$ by HA may reduce the bioavailability of $\mathrm{Cd}$ in the culture media, thereby limiting the absorption of Cd by the root of Iris sibirica L. Comparatively, STPP molecule is rather small with the molecule weight of just 367.86. This kind of small molecule might be easily absorbed by plants. Chelation of $\mathrm{Cd}$ would increase the total absorption of $\mathrm{Cd}$, because STPP might act as a carrier and bring Cd into root cells [22,23]. Finally, STPP exhibited a promoting effect on Cd accumulation in Iris sibirica L. Similarly, EDTA is also a small molecule chelator, which also promotes $\mathrm{Pb}$ accumulation in the terrestrial plant of Brassica juncea and the accumulation of $\mathrm{Pb}$ increases at a higher level of EDTA [24]. The effect of PASP and RLs might be between HA and STPP. At low levels, they might be absorbed by plants and carry more Cd into cells. At high levels, the concentration of PASP and RLs might exceed the absorption capacity of the plant. Thus, a high proportion of chelators remained in the media, which reduced the free $\mathrm{Cd}$ molecules in the solution that 
could be directly absorbed by the plant. In addition, high concentrations of chelators may also inactivate transporter proteins that minimized $\mathrm{Cd}$ absorption and transportation [25].
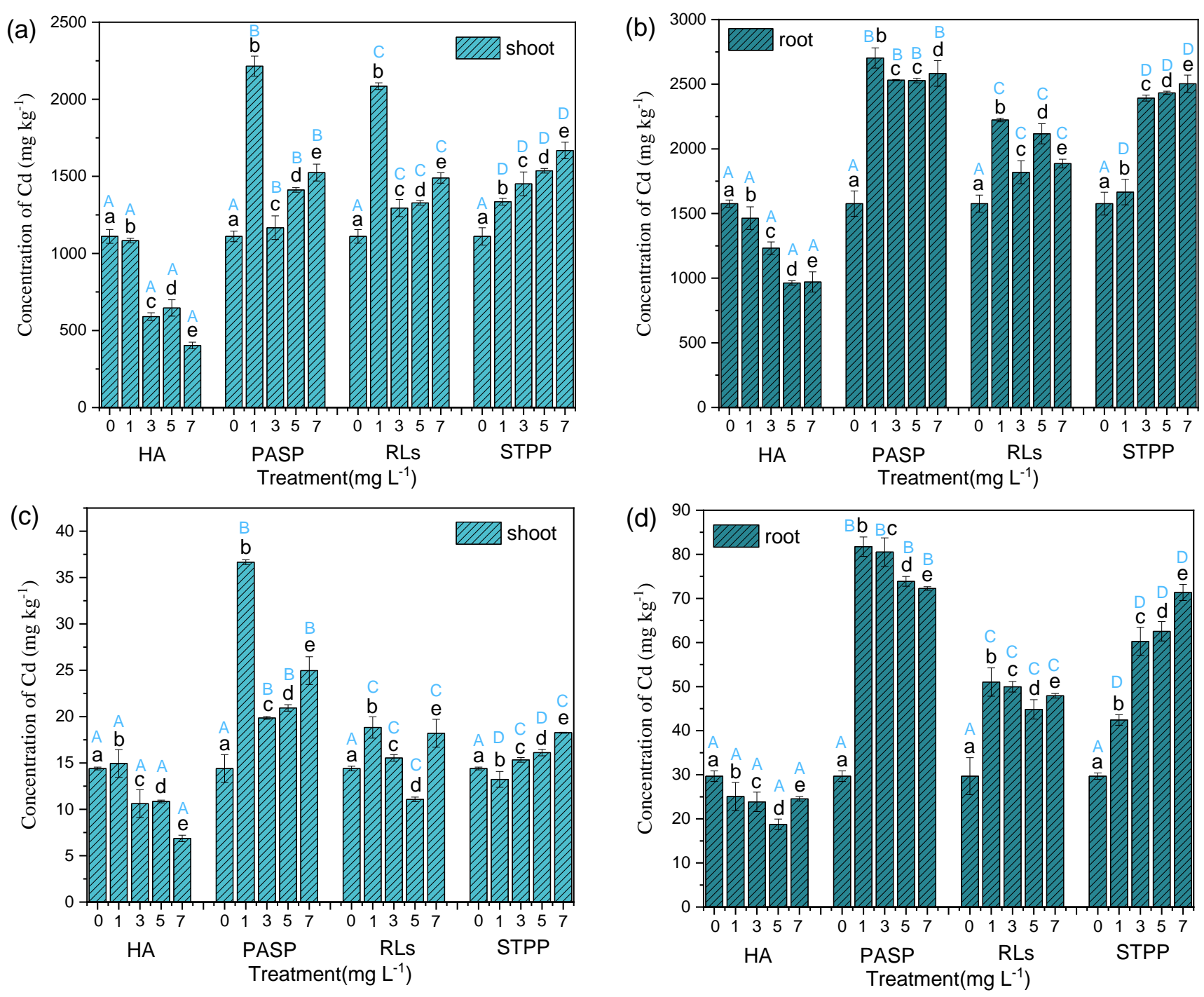

Figure 3. Concentration $(\mathbf{a}, \mathbf{b})$ and accumulation $(\mathbf{c}, \mathbf{d})$ of $\mathrm{Cd}$ in Iris sibirica L. with HA, PASP, RLs, and STPP under $25.00 \mathrm{mg} \mathrm{L}{ }^{-1} \mathrm{Cd}$. Note: shoot $\mathrm{Cd}$ concentration is calculated as: $\left(\mathrm{C}_{\text {stem }} \times \mathrm{M}_{\text {stem }}+\mathrm{C}_{\text {leaf }} \times \mathrm{M}_{\text {leaf }}\right) /\left(\mathrm{M}_{\text {stem }}+\mathrm{M}_{\text {leaf }}\right)$; shoot Cd accumulation is $\left(C_{\text {stem }} \times M_{\text {stem }}+C_{\text {leaf }} \times M_{\text {leaf }}\right)$, where $C$ is the concentration of $C d$ and $M$ is the biomass of the plant. Results are expressed as means \pm S.D. $(n=3)$. Different uppercase letters $(A-D)$ indicate significant differences between treatments with different chelators at the same concentration, and different lowercase letters (a-e) indicate significant differences between different concentrations of the same chelator.

Overall, the Cd concentration in Iris sibirica L. with the four chelators exhibited excellent similarities and differences; the amount of $\mathrm{Cd}$ in root was always higher than the other two parts. The results suggested that $\mathrm{Cd}$ accumulation in the roots was mainly related to the transportation mode of heavy metal in plants. Most heavy metal ions firstly entered into the plant root cells by the means of root absorbing and then were controlled through specific transport proteins [26]; they were transported through xylem conduit and finally moved to the plant stems and leaves $[27,28]$. Actually, due to cortical barrier effect, the cortex can help prevent the heavy metal migration between roots and shoots [29]. This also explains the good tolerance of plants to high concentration of metal ions [30]. 


\subsection{BCF and TCF}

$\mathrm{BCF}$ reflects the capacity of plants to extract hazardous materials from the environment [31]. Usually, the BCF values are more significant than the concentration in the shoot when considering the ability of phytoextraction [32]. In this study, among different organs, the minimum BCF values of Cd in treatments with RLs, STPP, PASP, and HA were 51.78, 53.42, 46.68, and 16.13, respectively (Figure 4a), displaying significant effects of phytoextraction and bioaccumulation. Even though all plants exert acceleration in capturing $\mathrm{Cd}$ compared to the control, the impact extent of chelators concentration on the amount of $\mathrm{Cd}$ detected in the plants was variable. When plants added with RLs, the change of BCF values were similar to that of PASP. Both of them were observed as a M shape pattern and the maximum data were detected at the concentration of $1.00 \mathrm{mg} \mathrm{L}^{-1}$. The mechanism of chelators on the uptake of heavy metals in plants has been investigated; one approach of mobilizing metals is forming complexes with metal ions in soil, then the complexes can move through roots and migrated to the shoot. Moreover, the chelators may enter into roots directly, then forming complexes with heavy metal and chelator in cell of plant, which could elevate the transportation of heavy metal in shoot tissues. High concentration chelators also could inactivate transporter proteins so that the mobilizing and translocation of metal in plant are minimized. Therefore, it might be speculated that high concentration biochelator would limit the formation of Cd-chelating complexes and finally weakened the ability of metal uptake from nutrient solutions with $\mathrm{Cd}^{2+}$. Different from the RLs and PASP, the BCF values were increased linearly from 44.42 to 68.62 with the increasing STTP concentrations. It can be inferred that only high concentration STTP could effectively enhance the accumulation of $\mathrm{Cd}$ in Iris sibirica L. Combined with the analysis mentioned above, it is concluded that the STPP and HA added in Iris sibirica L. can all facilitate the targeted plant Iris sibirica L. to improve the Cd absorption from the hydroponic solution.
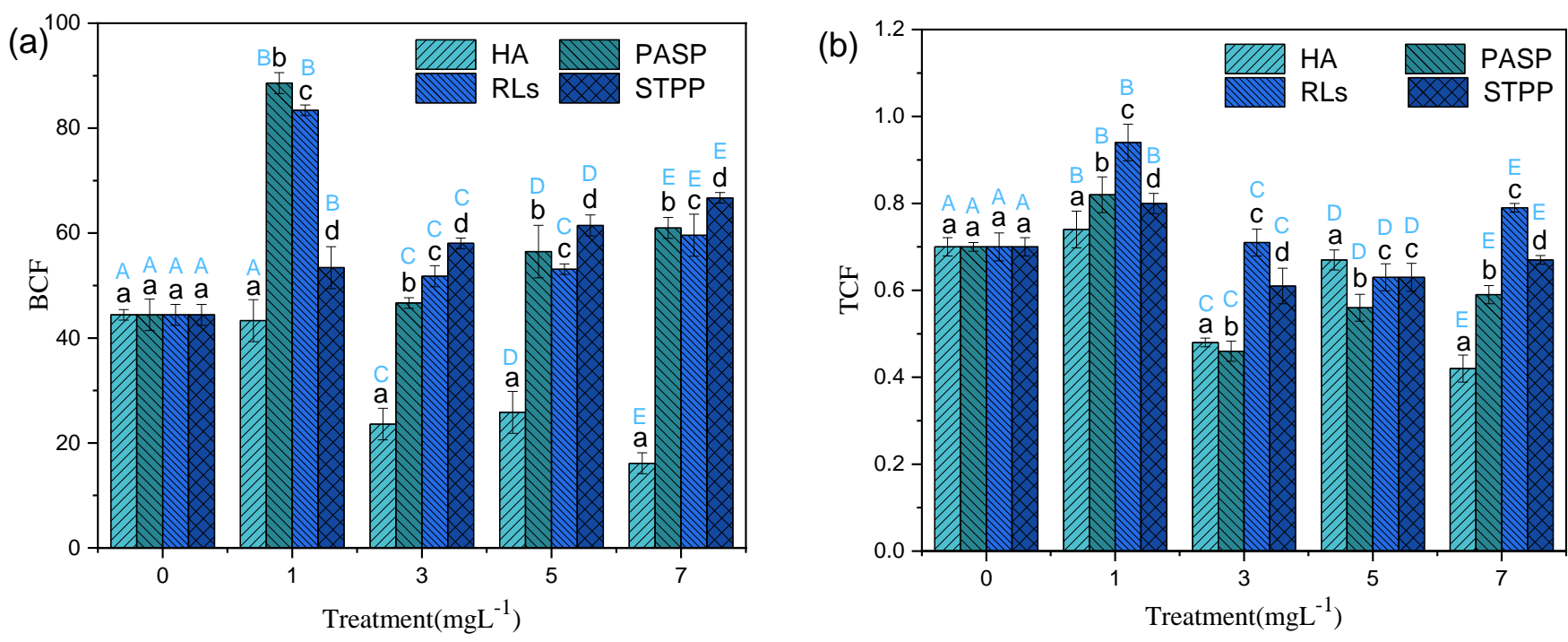

Figure 4. BCF (a) and TCF (b) for Iris sibirica L. with HA, PASP, RLs, and STPP under $25.00 \mathrm{mg} \mathrm{L}^{-1} \mathrm{Cd}$. Results are expressed as means \pm S.D. $(n=3)$. Different uppercase letters $(A-E)$ indicate significant differences between treatments with different chelators at the same concentration, and different lowercase letters $(\mathrm{a}-\mathrm{d})$ indicate significant differences between different concentrations of the same chelator.

TCF is an index to evaluate the transfer ability of pollutants from underground to above ground. Since the above ground part of plants is much easier to collect than the underground part, plants with high TCF values would be more convenient to operate for removing heavy metals from paddy fields [33]. In the present study, all the TCF values were lower than one (Figure $4 \mathrm{~b}$ ), indicating that there are more $\mathrm{Cd}$ molecules stored in roots than in shoots, which might increase the difficulty to recover $\mathrm{Cd}$ from the plants after phytoremediation. The highest TCF values in treatments with RLs, STPP, PASP, and HA 
were $0.94,0.80,0.82$, and 0.74 , respectively. Compared with the single Cd treatment, the addition of $1 \mathrm{mg} \mathrm{L}^{-1}$ of all the four chelators significantly increased TCF values, but higher levels of HA, PASP, and STPP significantly decreased TCF values (Figure $4 \mathrm{~b}$ ). These results indicated that suitable amounts of chelators could effectively promote the transportation of $\mathrm{Cd}$ from roots to shoots. Moreover, the promotion effect of transporting $\mathrm{Cd}$ followed the order: RLs > PASP > STPP > HA. Biochelators have both hydrophilic and hydrophobic portions, which should reduce the surface tension and increase the mobility of heavy metals in the soil and plants [34].

\subsection{Effects of Chelators on the Antioxidant Indices in Cd-Polluted Iris Sibirica L.}

The activities of antioxidant enzymes, including SOD, POD, and CAT, are generally used as indicators to reflect the antioxidant stress of organisms $[35,36]$ and have been used to investigate the toxicity of $\mathrm{Cd}[37,38]$. In this study, SOD, POD, and CAT activities were greatly higher in roots than in leaves in all treatments (except SOD activity in the treatments with HA), which were consistent with the observation of antioxidant enzymes activities in Cu-polluted Rassica napus in response to citric acid treatments [39]. Higher antioxidants enzymes in roots were attributed to the abundant of heavy metal in the apoplast, whereas metal ions in leaves were distributed in both apoplast and symplast, causing an increasing of antioxidants enzymes for the need of defense responses (shown in Figure 5) [40].
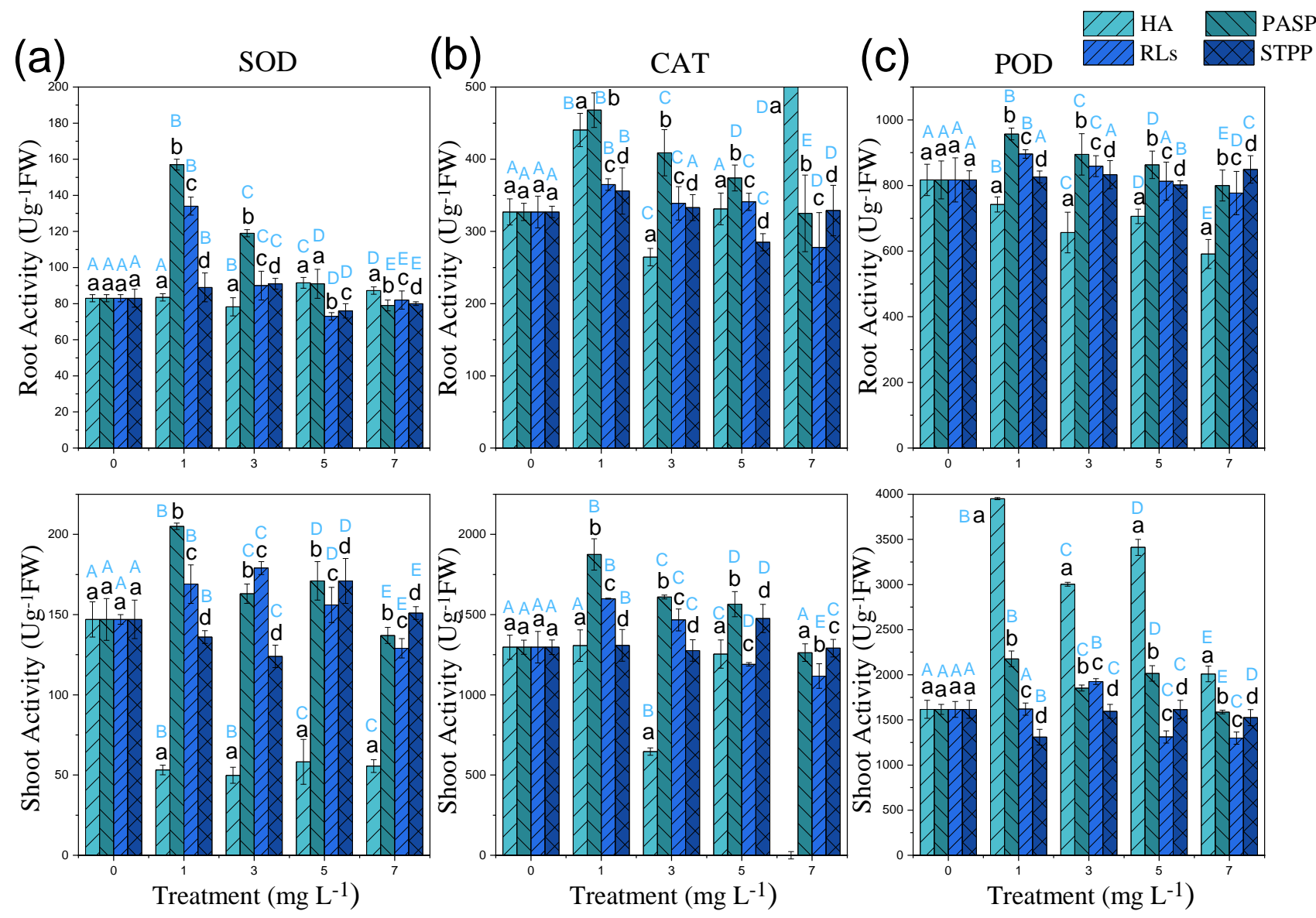

Figure 5. SOD (a), POD (b), CAT (c) activities in leaves and roots of Cd-polluted Iris sibirica L. in response to HA, PASP, RLs, and STPP treatments. Results are expressed as means \pm S.D. $(n=3)$. Different uppercase letters $($ A-E) indicate significant differences between treatments with different chelators at the same concentration, and different lowercase letters (a-d) indicate significant differences between different concentrations of the same chelator.

Compared with a single Cd treatment, low concentrations of PASP $\left(\leq 5.00 \mathrm{mg} \mathrm{L}^{-1}\right)$ and RLs ( $\left.\leq 3.00 \mathrm{mg} \mathrm{L}^{-1}\right)$ significantly increased the POD, SOD, and CAT activities of roots 
and leaves. Similar results were also observed in Cd-polluted B. napus treated with citric acid. Biochelators might elevate the activity of antioxidant enzymes to protect plants from heavy metals damage. However, STPP has little influence on antioxidant enzymes under all levels of stress, which meant that synthetic chelator might only relieve toxicity from heavy metal but not induce the activities of antioxidant enzymes. Conversely, HA strongly reduced the activities of antioxidant enzymes (except POD in root); this might be attributable to the defense of reactive oxygen species to antioxidant enzymes [41].

\section{Conclusions}

This study investigated the cadmium tolerance, accumulation characteristics, and the defense responses of antioxidants enzymes in the Cd treatment of Iris sibirica L. with the application of chelators. The application of HA significantly promoted the growth of Iris sibirica L. but reduced the accumulation of Cd in plants. PASP, RLs, and STPP can facilitate root growth but inhibited leaf growth, and more importantly, enhance the accumulation of $\mathrm{Cd}$ in Iris sibirica L. The treatment of PASP and RLs stimulates the antioxidant enzymes, which might protect plants from the harms of $\mathrm{Cd}$. Among the four chelators, PASP exhibited the best comprehensive efficacy in phytoremediation of $\mathrm{Cd}$ using Iris sibirica $\mathrm{L}$. Although studies in real wet soil are still needed to test the performance of PASP for Cd extraction, the findings in this study have demonstrated that PASP could be considered as the potential biochelator for Iris sibirica L. in Cd-contaminated paddy field.

Author Contributions: Conceptualization, Y.W. and S.L.; software, X.W.; validation, R.Y.; formal analysis, J.X.; investigation, T.L.; resources, J.Z.; data curation, X.W.; writing—original draft preparation, Y.W.; writing-review and editing, S.L.; visualization, J.Z.; supervision, L.W.; project administration, J.W.; funding acquisition, L.W. and M.C. All authors have read and agreed to the published version of the manuscript.

Funding: This research was funded by National Key Research and Development Program (2019YFC0408602), Guangxi innovation research team project (2018GXNSFGA281001), National Natural Science Foundation of China (51908375), Shenzhen Polytechnic Project (6020320003K), Shenzhen Science and Technology Innovation Commission (KJYY20180206180737010), the Department of education of Guangdong Province (2019GGCZX007), and research funds of The Guangxi Key Laboratory of Theory and Technology for Environmental Pollution Control (1901K001).

Institutional Review Board Statement: Not applicable.

Informed Consent Statement: Not applicable.

Data Availability Statement: Not applicable.

Conflicts of Interest: The authors declare no conflict of interest.

\section{References}

1. Clabeaux, B.L.; Navarro, D.A.; Aga, D.S.; Bisson, M.A. Combined effects of cadmium and zinc on growth, tolerance, and metal accumulation in Chara australis and enhanced phytoextraction using EDTA. Ecotoxicol. Environ. Saf. 2013, 98, 236-243. [CrossRef]

2. Ali, S.; Chaudhary, A.; Rizwan, M.; Anwar, H.T.; Adrees, M.; Farid, M.; Irshad, M.K.; Hayat, T.; Anjum, S.A. Alleviation of chromium toxicity by glycinebetaine is related to elevated antioxidant enzymes and suppressed chromium uptake and oxidative stress in wheat (Triticum aestivum L.). Environ. Sci. Pollut. Res. 2015, 22, 10669-10678. [CrossRef]

3. Rizwan, M.; Meunier, J.D.; Davidian, J.C.; Pokrovsky, O.S.; Bovet, N.; Keller, C. Silicon alleviates Cd stress of wheat seedlings (Triticum turgidum L. cv. Claudio) grown in hydroponics. Environ. Sci. Pollut. Res. 2016, 23, 1414-1427. [CrossRef]

4. Wan, S.; Li, Y.; Cheng, S.; Wu, G.; Gao, L. Cadmium removal by FeOOH nanoparticles accommodated in biochar: Effect of the negatively charged functional groups in host. J. Hazard. Mater. 2021, 421, 126807. [CrossRef]

5. Nemr, A.E.; El-Assal, A.; Sikaily, A.E.; Mahmoud, M.E.; Amira, M.F.; Ragab, S. New magnetic cellulose nanobiocomposites for $\mathrm{cu}(\mathrm{II}), \mathrm{cd}(\mathrm{II})$ and $\mathrm{pb}(\mathrm{II})$ ions removal: Kinetics, thermodynamics and analytical evaluation. Nanotechnol. Environ. Eng. 2021, 6, 1-20.

6. Guo, J.; Feng, R.; Ding, Y.; Wang, R. Applying carbon dioxide, plant growth-promoting rhizobacterium and EDTA can enhance the phytoremediation efficiency of ryegrass in a soil polluted with zinc, arsenic, cadmium and lead. J. Environ. Manag. 2014, 141, 1-8. [CrossRef] [PubMed] 
7. Rucandio, M.I.; Petit-Domínguez, M.D.; Fidalgo-Hijano, C.; García-Giménez, R. Biomonitoring of chemical elements in an urban environment using arboreal and bush plant species. Environ. Ence Pollut. Res. 2011, 18, 51-63. [CrossRef]

8. Luna, J.M.; Rufino, R.D.; Sarubbo, L.A.; Campos-Takaki, G.M. Characterisation, surface properties and biological activity of a biosurfactant produced from industrial waste by Candida sphaerica UCP0995 for application in the petroleum industry. Colloids Surf. B Biointerfaces 2013, 102, 202-209. [CrossRef]

9. Jadia, C.D.; Fulekar, M.H. Phytotoxicity and Remediation of Heavy Metals by Alfalfa (Medicago sativa) in Soil-vermicompost Media. Adv. Nat. Appl. Ences 2008, 2, 141-151.

10. Xu, Y.; Zhao, L.L.; Wang, L.N.; Xu, S.Y.; Cui, Y.C. Synthesis of polyaspartic acid-melamine grafted copolymer and evaluation of its scale inhibition performance and dispersion capacity for ferric oxide. Desalination 2012, 286, 285-289. [CrossRef]

11. Feng, R.; Wang, X.; Wei, C.; Tu, S. The Accumulation and Subcellular Distribution of Arsenic and Antimony in Four Fern Plants. Int. J. Phytoremediat. 2015, 17, 348-354. [CrossRef]

12. Juwarkar, A.A.; Nair, A.; Dubey, K.V.; Singh, S.K.; Devotta, S. Biosurfactant technology for remediation of cadmium and lead contaminated soils. Chemosphere 2007, 68, 1996-2002. [CrossRef] [PubMed]

13. Manzatu, C.; Nagy, B.; Ceccarini, A.; Iannelli, R.; Giannarelli, S.; Majdik, C. Laboratory tests for the phytoextraction of heavy metals from polluted harbor sediments using aquatic plants. Mar. Pollut. Bull. 2015, 101, 605-611. [CrossRef]

14. Sainger, P.A.; Dhankhar, R.; Sainger, M.; Kaushik, A.; Singh, R.P. Assessment of heavy metal tolerance in native plant species from soils contaminated with electroplating effluent. Ecotoxicol. Environ. Saf. 2011, 74, 2284-2291. [CrossRef] [PubMed]

15. Mulligan, C.N. Recent advances in the environmental applications of biosurfactants. Curr. Opin. Colloid Interface Sci. 2009, 14, 372-378. [CrossRef]

16. Xin, Z.; Shi, L.; Liu, X.; Han, Z.; Li, L.; Tan, T. The research of enhancing phytoremediation of heavy metals contaminated soil with PASP. Chin. Agric. Sci. Bull. 2013, 29, 151-156.

17. Zhen, M.; Chen, H.; Liu, Q.; Song, B.; Wang, Y.; Tang, J. Combination of rhamnolipid and biochar in assisting phytoremediation of petroleum hydrocarbon contaminated soil using spartina anglica. J. Environ. Sci. 2019, 85, 107-118. [CrossRef]

18. Wei, J.; Yang, H.; Cao, H.; Tan, T.; Ashraf, M.A. Using polyaspartic acid hydro-gel as water retaining agent and its effect on plants under drought stress. Saudi J. Biol. Sci. 2016, 23, 654-659. [CrossRef]

19. Ifon, B.E.; Alexis Crépin Finagnon Togbé, L.A.S.T.; Yessoufou, A. Metal-Contaminated Soil Remediation: Phytoremediation, Chemical Leaching and Electrochemical Remediation. In Metals in Soil_Contamination and Remediation; Zinnat, A.B., Rahman, I.M.M., Hasegawa, H., Eds.; IntechOpen: London, UK, 2019; pp. 102-115.

20. Huang, R.; Dong, M.; Mao, P.; Zhuang, P.; Li, Z. Evaluation of phytoremediation potential of five cd (hyper)accumulators in two cd contaminated soils. Sci. Total Environ. 2020, 721, 137581. [CrossRef] [PubMed]

21. Shaohui, X.U.; Jiang, D.; Shi, D.; Zhang, R.; Huang, Z.; Yang, G. Screening and identification of lead and cadmium resistant microorganisms from combined heavy metal pollution soil. Chin. J. Appl. Environ. Biol. 2019, 3, 532-538.

22. Wu, L.; Luo, Y.; Song, J. Manipulating Soil Metal Availability Using EDTA and Low-Molecular-Weight Organic Acids. Phytoremediation 2007, 23, 291-303.

23. Wenzel, W.W.; Unterbrunner, R.; Sacco, S.P. Chelate-assisted phytoextraction using canola (Brassica napus L.) in outdoors pot and lysimeter experiments. PlantSoil 2003, 249, 83-96.

24. Vassil, A.D.; Kapulnik, Y.; Salt, R.D.E. The Role of EDTA in Lead Transport and Accumulation by Indian Mustard. Plant. Physiol. 1998, 117, 447-453. [CrossRef]

25. do Nascimento, C.W.A.; Amarasiriwardena, D.; Xing, B. Comparison of natural organic acids and synthetic chelates at enhancing phytoextraction of metals from a multi-metal contaminated soil. Environ. Pollut. 2006, 140, 114-123. [CrossRef] [PubMed]

26. Stanley, R.; Arpa, G.; Sakulas, H.; Harakuwe, A.; Timi, D. Phytoremediation-An Eco-friendly and Sustainable Method of Heavy Metal Removal from Closed Mine Environments in Papua New Guinea. Procedia Earth Planet. Sci. 2013, 6, 269-277. [CrossRef]

27. Schröder, P. Uptake, translocation and possible biodegradation of the antidiabetic agent metformin by hydroponically grown Typha latifolia. J. Hazard. Mater. 2016, 308, 355-361.

28. Rocha, A.C.S.; Almeida, C.M.R.; Basto, M.C.P.; Vasconcelos, M.T.S.D. Marsh plant response to metals: Exudation of aliphatic low molecular weight organic acids (ALMWOAs). Estuar. Coast. Shelf Sci. 2016, 171, 77-84. [CrossRef]

29. Orlowska, E.; Przybytowicz, W.; Orlowski, D.; Mongwaketsi, N.P.; Turnau, K.; Mesjasz-Przybylowicz, J. Mycorrhizal colonization affects the elemental distribution in roots of Ni-hyperaccumulator Berkheya coddii Roessler. Environ. Pollut. 2013, 175, 100-109. [CrossRef]

30. Zhang, X.; Zhu, Y.; Zhang, Y.; Liu, Y.; Liu, S.; Guo, J.; Li, R.; Wu, S.; Chen, B. Growth and metal uptake of energy sugarcane (Saccharum spp.) in different metal mine tailings with soil amendments. J. Environ. Sci. 2014, 26, 1080-1089. [CrossRef]

31. Mcgeer, J.C.; Brix, K.V.; Skeaff, J.M.; Deforest, D.K.; Brigham, S.I.; Adams, W.J.; Green, A. Inverse relationship between bioconcentration factor and exposure concentration for metals: Implications for hazard assessment of metals in the aquatic environment. Environ. Toxicol. Chem. 2003, 22, 1017-1037. [CrossRef]

32. Redondo-Gómez, S.; Mateos-Naranjo, E.; Andrades-Moreno, L. Accumulation and tolerance characteristics of cadmium in a halophytic Cd-hyperaccumulator, Arthrocnemum macrostachyum. J. Hazard. Mater. 2010, 184, 299-307. [CrossRef]

33. Rezvani, M.; Zaefarian, F. Bioaccumulation and translocation factors of cadmium and lead in Aeluropus littoralis. Aust. J. Agric. Eng. 2011, 2, 114-119. 
34. Rahman, K.S.M.; Rahman, T.J.; Kourkoutas, Y.; Petsas, I.; Marchant, R.; Banat, I.M. Enhanced bioremediation of n-alkane in petroleum sludge using bacterial consortium amended with rhamnolipid and micronutrients. Bioresour. Technol. 2003, 90, 159-168. [CrossRef]

35. Ali, S. The interaction of salinity and chromium in the influence of barley growth and oxidative stress. Plant. Soil Environ. 2011, 57, 153-159. [CrossRef]

36. Haouari, C.C.; Nasraoui, A.H.; Bouthour, D.; Gouia, H. Response of tomato (Solanum lycopersicon) to cadmium toxicity: Growth, element uptake, chlorophyll content and photosynthesis rate. Afr. J. Plant Sci. 2012, 6, 001-007.

37. Kling, P.G.; Olsson, P.E. Involvement of differential metallothionein expression in free radical sensitivity of RTG-2 and CHSE-214 cells. Free Radic. Biol. Med. 2000, 28, 1628-1637. [CrossRef]

38. Zhang, F.; Zhang, H.; Wang, G.; Xu, L.; Shen, Z. Cadmium-induced accumulation of hydrogen peroxide in the leaf apoplast of Phaseolus aureus and Vicia sativa and the roles of different antioxidant enzymes. J. Hazard. Mater. 2009, 168, 76-84. [CrossRef]

39. Zaheer, I.E.; Ali, S.; Rizwan, M.; Farid, M.; Shakoor, M.B.; Gill, R.A.; Najeeb, U.; Iqbal, N.; Ahmad, R. Citric acid assisted phytoremediation of copper by Brassica napus L. Ecotoxicol. Environ. Saf. 2015, 120, 310-317. [CrossRef]

40. Pallara, G.; Todeschini, V.; Lingua, G.; Camussi, A.; Racchi, M.L. Transcript analysis of stress defence genes in a white poplar clone inoculated with the arbuscular mycorrhizal fungus Glomus mosseae and grown on a polluted soil. Plant. Physiol. Biochem. Ppb. 2013, 63, 131-139. [CrossRef]

41. Freeman, J.L. Increased Glutathione Biosynthesis Plays a Role in Nickel Tolerance in Thlaspi Nickel Hyperaccumulators. Plant. Cell 2004, 16, 2176-2191. [CrossRef] 